\title{
Yeast Protein Complex
}

National Cancer Institute

\section{Source}

National Cancer Institute. Yeast Protein Complex. NCI Thesaurus. Code C19800.

Any protein complex found in yeast. 